[Vicino Oriente XX (2016), pp. 59-84]

\title{
JAMAAN AT THE PASS OF BI'REIN AN IRON AGE IIB-C AMMONITE STRONGHOLD IN CENTRAL JORDAN
}

\author{
Lorenzo Nigro $^{1}$ - Sapienza University of Rome \\ Romeel Gharib ${ }^{2}$ - Ministry of Tourism and Antiquities \\ of the Hashemite Kingdom of Jordan
}

In years 2015-2016 the Zarqa Directorate of the Department of Antiquities of the Hashemite Kingdom of Jordan carried out a rescue excavation at the site of Jamaan, an Iron Age IIB-C Ammonite stronghold $16 \mathrm{Km}$ north of 'Amman. The site survey and limited soundings allow to plot a plan of the structure, comprising an outer enclosure with a casemate wall, two cisterns, and a square podium tower, and to collect ceramic material dating from Iron Age IIB-C (c. 840-580 BC), as well as the head of a soft limestone statue, possibly depicting a local chief or an official. The latter adds to the relatively conspicuous number of statues from the Kingdom of Ammon, possibly illustrating the production of a non-royal commission. ${ }^{3}$

Keywords: Ammon; fortress; Iron Age IIB-C; statuary; Neo-Assyrian

\section{INTRODUCTION}

The site of Jamaan ${ }^{4}$ is located in the Governorate of Zarqa - sub-district of Bi'rein, in the Hashemite Kingdom of Jordan, about $16 \mathrm{Km}$ north of 'Amman. The site lays $0.72 \mathrm{Km}$ south of the ancient ruins of Khirbet Zuby'a and $0.5 \mathrm{Km}$ east of the village and small tell of Bi'rein (modern dialect corruption of Bî'rayn, "the two cisterns", which are actually a distinguishing feature of Jamaan), just south of the main road running from Wadi Shomar, a left (western) tributary of the Zarqa River, over the pass introducing into Wadi Fatayer and in the underlying Sahl al-Buqey'a (fig. 1).

In antiquity, Wadi Shomar was a useful shortcut straightly connecting the ford across the Zarqa by Jneneh ${ }^{5}$ and Batrawy with the $10 \mathrm{Km}$-far to the east Pass of Bi'rein, allowing a faster and direct access to the southern Jordan Valley through the es-Salt/Balqa district (Wadi Azraq, Wadi Shuay'ib, Wadi Nimrin). Jamaan lays exactly in correspondence of the pass (elevation $825 \mathrm{~m}$ above the sea level) at a clear bent-turn of the ancient road, leading westwards to the $3 \mathrm{Km}$-far site of Umm Rummana. ${ }^{6}$

Director of Rome Sapienza Expedition to Palestine \& Jordan (ROSEPAJ).

2 Director of Zarqa Directorate of Antiquities of the DoA.

3 The two Authors wish to deeply thank the DoA General Director, H.E. Dr Monther Jamhawi, and the Director of Excavations \& Surveys, Dr Aktham Abbadi, for their constant and friendly support.

4 Jamaan is the current name of the site and it can be traced back only into the second half of the $20^{\text {th }}$ century $\mathrm{BC}$, when new groups of nomads settled in the area of Bi'rein. It is not mentioned in previous surveys of the region, it was not - somewhat surprisingly - mentioned in N. Glueck's Exploration of Eastern Palestine (III) or in other following surveys. The site does not appear in MEGA Jordan (where the two nearby "Zoobya" and "Bi'rein" are instead present). This is possibly due to its location just inside the ridge of the pass, which made it not visible from the west, where the main road passes by.

5 Sala 2008, 366-367.

6 Not to be confused with Ar-Rumman of the Gordon - Knauf survey of Abu Thawwab (1987), which lays further west.

ISSN 0393-0300

e-ISSN 2532-5159 
The exploration of Jamaan was in fact due to the renovation and upgrade of this road, which cuts through it from north-east to south-west. The road was doubled and became a motorway, with a somewhat destructive impact on the site.

In 2014, due to this threaten, the Department of Antiquities of Jordan planned a rescue intervention, which was successively carried out in 2015 and 2016 by the Zarqa Directorate, under the direction of Mr Romeel Gharib, and with the participation of the surveyor Taufik al-Huniti. The site was, thus, mapped, carefully surveyed, thoroughly explored and, at the end of the rescue archaeological work, its main feature, a monumental square tower, was dismantled and rebuilt on the nearby site of Khirbet Zuby'a.

A restricted team of Rome Sapienza University was involved with the personnel of the DoA office of Zarqa for the study of finds (basically pottery and small finds) and for the reconstruction of stratigraphy and architecture of this monument. Jordanian and Italian personnel worked as a unique team, and this provisional report is the fruit of their joint work.

Two seasons of excavations took place at Jamaan, the first one from $1^{\text {st }}$ to $30^{\text {th }}$ October 2015, and the second one between $1^{\text {st }}$ and $30^{\text {th }}$ April 2016. The re-displacement of the main tower was carried out by the DoA Zarqa Directorate immediately after this date.

\section{GEOMORPHOLOGY, TOPOGRAPHY AND HISTORICAL GEOGRAPHY}

The location of Jamaan is strategic: at the centre of the valley and in correspondence of the pass, where the road to the nearby towns of Zuby'a and Bî'rayn, with a sharp curve, starts to descend steep into the underlying wadi. It slightly raises to the west, due to a rocky edge emerging at the pass. Actually, already in antiquity the road was cut through these rocks (fig. 2).

The flat and cultivable bottom of the valley, $500 \times 300 \mathrm{~m}$, on the border of which the tower and its precinct were erected, may assure the necessary agricultural supply to the stronghold. Moreover, the two cisterns of Jamaan offered a safe water source to caravans climbing back and forth the pass on the track connecting the Syro-Arabic Desert, the Zarqa River and the Jordan Valley. The site lays also at the border between $200 \mathrm{~mm}$ isohyet and the dry-farming highlands of the Buqey'a Valley and the steppes environment which extends across the Zarqa River until the desert to the east.

During pre-classical antiquity, and especially in the Iron Age IIB-C (c. 840-580 BC), which is the approximately date indicated by ceramic finds at Jamaan (see below $§ 5.1$.), this area was under the control of the king of Ammon, ruling from Rabbath Ammon, the capital-city of the Ammonite Nation, identified with Jebel al-Qal'a, the Citadel of present times 'Amman. ${ }^{7}$ Ancient sources and inscriptions referring to the kingdom of Ammon during this time span, thus, may help in fixing the geographic and historical setting of Jamaan (§ 3.).

The "House of Ammon" was protected by means of forts and strongholds erected by crossroads or on top-hills overlooking vast portions of territory, as well as in strategic geomorphological locations like passes and fords especially on its western and southern

7 Zayadine - Humbert - Najjar 1989; Mansour 2002. 
boundaries. ${ }^{8}$ Moreover, such structures usually punctuated the Kings' Highway and its branches running over the Transjordanian Highlands.

After Nelson Glueck's exploration of Eastern Palestine (III), ${ }^{9}$ a line of fortresses and towers was put on the map NNW of 'Amman, ${ }^{10}$ interpreted as the western border of the Iron Age IIB-C (840-586 BC) kingdom of Ammon. ${ }^{11}$ Several other surveys followed, ${ }^{12}$ but no decisive evidence was produced to support this view with more precise dating and structural classification. ${ }^{13}$ Scholars cyclically labeled "Ammonite fortresses" a series of monumental structures made of large limestone boulders punctuating the region south, west and north of 'Amman, which exhibit different features, ${ }^{14}$ e.g. some of them being square (qasrs) and other round (rujum), ${ }^{15}$ and often also diverse chronologies. ${ }^{16}$ Nevertheless, none of these surveys enlisted Jamaan, probably because they involuntarily passed by Wadi Shomar. ${ }^{17}$

Anyhow, what seems clear, is that the orographic step dividing the district comprised within the bent of the Zarqa River, from the valleys of es-Salt and Balqa and the mountain range between them and the Jordan, became a natural border in antiquity. This border was marked by multiple lines (a network) of fortresses and strongholds, located in the Buqey'a itself, and on the most prominent positions over the highest hill range west of the Zarqa River. ${ }^{18}$ The innermost line in respect of Rabbath Ammon run NNE from Khilda to Jubeiha, Khirbet Bedran, continuing further north up to the definitive bend westwards of the Zarqa River. Here, it seems plausible that the northern border of Ammon on the Zarqa

8 Stern 2001, 246-247.

9 Glueck 1939, 151-261.

10 Glueck 1939, 246-247.

11 On the extension of "Bene Ammon", after the Old Testament, a positive critical synthesis of almost a century of studies and discussion was offered by R.J. Bartlett (1970, 260), though always pivoted on the statement "from the Arnon to the Jabbok and to the Jordan" (Judg. 11:13). Biblical traditions about Ammonite territory and boundaries are numerous and sometimes contradictory (MacDonald 1999, 30-39), as in the same esSalt/Balqa region they locate the tribe of Gad, Sihon, the king of Amorites, and Og, the king of Bashan (Num. 32, 33; 1 Kings 4:19; Judg. 10:8; Josh. 12:1-6, 22:9).

12 Gese 1958; Hentschke 1960; Fohrer 1961; Graf-Revcmlow 1963; for an exhaustive synthesis see: Younker 1999, 11-15.

13 The functions and date of the so-called "Ammonite towers" have been widely discussed by the scholars (for summaries on this topic, see: Yassine 1988, 16-19; Kletter 1991; Najjar 1999).

14 These structures are also called "Malfuf buildings”, like “cabbage towers” (Kletter 1991; see also MacDonald 1999, 41-42).

15 Glueck 1939, 155

16 Actually, the date of such watchtowers varies considerably from the Iron Age to the Ottoman period, with many possible reuses (Najjar 1999, 103-104). The fortresses surely in use during Iron Age II are: Rujm alMalfuf North (Yassine 1988, 17), Rujm al-Malfuf South (Thompson 1973, 47-50; Najjar 1999, 105), Rujm alHenu and Rujm al-Hawi (Clark 1983; McGovern 1983, 136; 1986, 9; 1989, 40-42), Rujm al-Mekhayzin (Thompson 1984, 38), Khilda (Najjar 1992, 14-20), Jubeiha (Muheisen 1976), Khirbat Salama (Lenzen McQuitty 1987, 203; 1989, 544), Khirbet al-Hajjar (Thompson 1972, 62; 1977, 29).

17 The same happened for Qal'at Hamra, Jneneh, and Khirbet al-Batrawy (not to be confused with Kh. Beitrawi, $3 \mathrm{Km}$ north of the latter).

18 These sites constituted a chain of forts along the Ammonite border (Gese 1958, 57, 63); this theory has been recalled by R. Kletter (1991, 43-44, fig. 10), and U. Hübner (1992, 141-150). 
River was protected by a major fortress on the site of Tell el-Bireh (fig. 3), which lays 4.5 Km south of the river curve, and $9.5 \mathrm{Km}$ north of Jamaan. ${ }^{19}$

The network of fortresses surrounding 'Amman in which Jamaan was included has been regarded in turn as the western border of Ammon during the times of the confrontation with Israelites, ${ }^{20}$ or, more convincingly, as the limes of the Neo-Assyrian vassal state of BîtAmmani (fig. 4). ${ }^{21}$ This second reconstruction seems corroborated by finds at the site.

In the last decades an unprecedented urban development in the districts of 'Amman, esSalt, Balqa, and Zarqa has deeply impacted on archaeological sites, many of which lay submerged by modern buildings. Most recent surveys and excavations, mainly focused on small prehistoric sites, dolmens, cairns and other multi-period installations for the sake of their safeguard and correct location on official maps, achieved the highly commendable task of saving invaluable information and produced fresh archaeological data now converged into MEGA Jordan. ${ }^{22}$ They, however, could not bridge the lack of information descending from proper excavations, and in some rare cases, failed in reporting major archaeological features (which were not regarded as unknown!). Thanks to the DoA Zarqa Directorate painstaking commitment, this site, previously almost completely neglected by archaeologists, was documented and its historical-archaeological role in the Iron Age acknowledged. After the rescue seasons of 2015 and 2016, it became clear that Jamaan was a stronghold on a main track connecting the Zarqa River to the Jordan Valley during the times of the great Ammonite Kingdom of the $9^{\text {th }}-6^{\text {th }}$ century BC.

\section{HistoriCAL SETTING: AMMON UNDER THE NEO-ASSYRIAN AND NEO-BABYLONIAN RULE}

During the Iron Age II, Upper and Middle Wadi az-Zarqa (biblical Jabbok) and its tributaries were the core of the kingdom of Ammon, Bît-Ammani in Neo-Assyrian texts, known as early as the reign of Shalmaneser III (858-824 BC), for its king Ba'asa took part to the coalition of forces gathered by the king of Soba/Damascus against the invading NeoAssyrians army at the epochal battle of Qarqar on the Orontes in 853 BC. ${ }^{23}$ Actually, the earliest document on the Ammonite kingdom was found in Jebel al-Qal'a, i.e. the 'Amman Citadel, ${ }^{24}$ ancient Rabbath Ammon, ${ }^{25}$ which also mention the national god of the Ammonites, MLKM. ${ }^{26}$

19 Sala 2008, 369-371.

20 Gese 1958, 57; Fohrer 1961, 66; Landes 1961, 73; Graf-Revcmlow 1963, 136-137.

21 Kletter 1991, 42-44; Lipschits 2004, 41. Actually these authors based their speculations on data extracted by previous works and surveys (basically Glueck’s and Gese’s surveys).

22 More than a century of archaeological investigations allowed to identified almost the totality of archaeological sites also in the central Jordanian sub-district of Bi'rein, as a visit to the web-site MEGA Jordan (www.megajordan.org) can easily illustrate.

23 Lawson Younger 2003.

24 Known as the 'Amman Citadel inscription: Horn 1969; Albright 1970, who dated it to the $9^{\text {th }}$ century BC.

25 Rabbatbĕne 'Ammōn, "the Great (City) of the Children of Ammon”, according to 2 Sam. 12:26, 29.

26 Usually the god of Ammon is called Milkom (1 Kings 11:5, 33; 2 Kings 23:13), but this might descend from the connection with royalty, being the divine name used in official contexts and not the real name of the god, appearing in the kings’ names “El” (Joffe 2002, 449-450; van der Veen 2012). 


\begin{tabular}{|c|c|c|c|c|c|}
\hline Date & $\begin{array}{l}\text { Assyria \& } \\
\text { Babylonia }\end{array}$ & Ammon & Moab & Israel & Judah \\
\hline $\begin{array}{l}1020 \\
1010 \\
970\end{array}$ & $\begin{array}{l}\text { Ashur-nirari IV } \\
\text { Ashur-rabi } \\
\text { Ashur-reshi-ishi II } \\
\text { Tiglath-pileser II }\end{array}$ & $\begin{array}{l}\text { Nahạas } \\
\text { Hanun, Sobi }\end{array}$ & & \multicolumn{2}{|c|}{$\begin{array}{c}\text { Saul (1020-1010) } \\
\text { David (1010-970) } \\
\text { Solomon (970-930) }\end{array}$} \\
\hline 900 & $\begin{array}{l}\text { Ashur-dan II } \\
\text { Adad-nirari II }\end{array}$ & Ruhubi (?) & & $\begin{array}{l}\text { Jeroboam I (930-910) } \\
\text { Nadab (910-908) } \\
\text { Baasha (908-886) }\end{array}$ & $\begin{array}{l}\text { Rehoboam (930-913) } \\
\text { Abijah (913-911) } \\
\text { Asa (911-870) }\end{array}$ \\
\hline 850 & $\begin{array}{l}\text { Tukulti-Ninurta I } \\
\text { Ashurnasirpal II } \\
\text { Shalmaneser III }\end{array}$ & $\begin{array}{l}\text { (?) } \\
\text { Ba’asa }\end{array}$ & Mesha (c. 850) & $\begin{array}{l}\text { Elah,Zimri,Omri, } \\
\text { Ahab (886-853) } \\
\text { Ahaziah (853-852) } \\
\text { Joram (852-841) } \\
\end{array}$ & $\begin{array}{l}\text { Jehoshaphat (870-848) } \\
\text { Jehoram, Ahaziah, }\end{array}$ \\
\hline 800 & $\begin{array}{l}\text { Shamshi-Adad V } \\
\text { Adad-nirari III }\end{array}$ & & & $\begin{array}{l}\text { Jehu (841-814) } \\
\text { Jehoahaz (814-798) } \\
\text { Jehoash (798-783) } \\
\end{array}$ & $\begin{array}{l}\text { Athaliah (848-835) } \\
\text { Joash (835-796) } \\
\text { Amaziah (796-781) } \\
\end{array}$ \\
\hline 750 & $\begin{array}{l}\text { Shalmaneser IV } \\
\text { Ashur-dan III } \\
\text { Ashur-nirari V }\end{array}$ & & & $\begin{array}{l}\text { Jeroboam II } \\
\text { (783-743) } \\
\text { Zechariah, Shallum }\end{array}$ & $\begin{array}{l}\text { Uzziah } \\
(781-740)\end{array}$ \\
\hline 700 & $\begin{array}{l}\text { Tiglath-pileser III } \\
\text { Shalmaneser V } \\
\text { Sargon II } \\
\text { Sennacherib }\end{array}$ & $\begin{array}{l}\text { Shanibu } \\
\text { (c. 735) } \\
\text { Zakir } \\
\text { Yerah-azar } \\
\end{array}$ & $\begin{array}{l}\begin{array}{l}\text { Salamanu } \\
\text { (c. 735) }\end{array} \\
\text { Kamosh-madbi } \\
\end{array}$ & $\begin{array}{l}\text { Menahem (743-738) } \\
\text { Pekahiah,Pekah, } \\
\text { Hoshea (743-724) } \\
\text { Conquest of Samaria } \\
\quad 722 \\
\end{array}$ & $\begin{array}{l}\text { Jotham (740-736) } \\
\text { Ahaz (736-716) } \\
\text { Hezekiah (716-687) }\end{array}$ \\
\hline 650 & $\begin{array}{l}\text { Esarhaddon } \\
\text { Ashurbanipal }\end{array}$ & $\begin{array}{l}\text { Pudu-Ilu } \\
\text { (700-675) } \\
\text { ‘Ammi-nadab I } \\
\text { (c. 660) }\end{array}$ & $\begin{array}{l}\text { (c. 700) } \\
\text { Musuri } \\
\text { (675-660) } \\
\text { Kamosh-halta } \\
\end{array}$ & & Manasseh (687-642) \\
\hline 600 & $\begin{array}{l}\text { Ashur-etil-ilani } \\
\text { Sin-shar-ishkun } \\
\text { Ashur-uballit II }\end{array}$ & $\begin{array}{l}\text { Hịșșal’el } \\
\text { ‘Ammi-nadab II }\end{array}$ & (c. 650) & & $\begin{array}{l}\text { Amon (642-640) } \\
\text { Josiah (640-609) } \\
\text { Jehoshaz (609) } \\
\text { Jehoiakin (609-598) }\end{array}$ \\
\hline 586 & $\begin{array}{l}\text { Kharran conquest } \\
\text { Nabopolassar } \\
\text { Nebuchadnezzar II }\end{array}$ & $\begin{array}{l}\text { Hanan'el } \\
\text { Ba’alys }\end{array}$ & & & $\begin{array}{l}\text { Jehoiachin (597) } \\
\text { Zedekiah (597-586) } \\
\text { Conquest of Jerusalem } \\
\text { Gedaliah }(586-582 / 1)\end{array}$ \\
\hline
\end{tabular}

Tab. 1 - Diachronic synopsis of the kings'lists of Assyria, Babylonia, Ammon, Moab, Israel and Judah in the first half of the $1^{\text {st }}$ millennium BC. The time-span of Jamaan is highlighted.

The list of kings of Ammon is known by a series of inscriptions ${ }^{27}$ and statues, ${ }^{28}$ from the second half of the $8^{\text {th }}$ century BC (tab. 1), when Ammonite kings Šanibu paid tribute to

27 Puech 1985; Kletter 1991, note 12; Stern 2001, 238-240.

28 Bienkowski 1991, 38-51; Zayadine 1991. 
Tiglath-pileser III (744-727 BC), Zakir and his son Yerah-azar ${ }^{29}$ to Sargon II (721-705 BC), Pudu-Ilu to Sennacherib (704-681 BC) and Esarhaddon (680-669 BC), and 'Amminadab I to Ashurbanipal (668-631 BC), ${ }^{30}$ who also campaigned in the country during his war against the Arabs. ${ }^{31}$ Ammon remained a vassal kingdom of Assyria also during the reigns of Ashurbanipal's successors between c. 630 and 610 BC, with the king Hișșal'el, and, successively, Ammi-nadab II both known from the inscription on Tell es-Siran bottle. ${ }^{32}$ With the definitive Assyrian defeat at Kharran in $610 \mathrm{BC}$, and after the accession to the throne of Nebuchadnezzar II (604-562 BC), also Ammon passed under NeoBabylonian sovereignty. ${ }^{33}$ The dynasty of 'Ammi-nadab I apparently held the power, with his grandson 'Ammi-nadab II, who reigned between c. 610 and 590 BC, and his successors Hanan'el and Ba'alys, who possibly was a contemporary of Gedaliah of Judah (Jer. 40:14). ${ }^{34}$

During the reigns of all these kings, Bît-Ammani remained a vassal kingdom of Assyrians, and after the advent of Nebuchadnezzar II, of Babylonians. In the meanwhile, Jamaan was one of the defensive strongholds of the kingdom. Its final destruction, marked by a fierce conflagration and by the abandonment of the tower occurred towards the mid of the $6^{\text {th }}$ century $\mathrm{BC}$, apparently when the Persians took the place of Babylonians in ruling over the country, transforming Ammon into a province of their empire. ${ }^{35}$

\section{ARCHITECTURE}

The stronghold of Jamaan consisted of a rectangular enclosure, with the longest western side overlooking the Pass of Bi'rein, including a raised podium which occupied its southwestern corner, and the main entrance on the northern short side (fig. 5). The fortress was defended by a double perimeter wall with casemates (21) in between. Structures were built with roughly cut limestone and quartz boulders of average dimensions $(0.7-0.8 \times 0.4-0.5$ $\mathrm{m})$, usually laid in two rows of superimposed courses tied up with mortar, pebbles and small stone chops. The interior of the walls was also filled up with medium size irregular stones.

The typology of the buildings is well known in Iron Age II Southern Levant, ${ }^{36}$ and it has been labelled 'citadel' even though this term describes palatial complexes and

29 Zakir and his son Yerah-azar are known thanks to the statue of the latter found in the 'Amman Citadel (Bienkowski 1991, 49-50, pl. 38; Burnett 2016a, fig. 2a), characterized by an inscription bearing the name of the king (Aufrecht 1989, 106-109, n. 43).

30 Pritchard ed. 1969, 282, 287, 294, 301

31 A renowned passage of the Rassam Cylinder describing the campaign of this king mentions the "pass of Iabrud” in between Udume and Bît-Ammanias one of the location of Arabs' defeats (Luckenbill 1927, 314). Although it was usually identified with Yabrud north of Damascus (the same text also mentions Zobah), one cannot rule out the possibility that this pass was actually located in a place like Jamaan, in central Jordan.

32 Thompson - Zayadine 1974; Bienkowski 1991, 141.

33 Lipschits 2004, 43-46.

34 van der Veen 2007; Burnett 2016b, 320

35 Stern 2001, 369

36 Nigro 1994, 203-291, 436-452; Bonfil - Zarzecki-Peleg 2007, 32-33; Lehmann - Killebrew 2010; Ripepi 2012. 
fortresses, which often exhibit strong dimensional variations. In this case, the overall area occupied by the stronghold was about 1.5 dunam (1536 sqm). Nonetheless, Jamaan, for its extension and plan, may be also compared with a fortified caravansary or a small castle. It may be reasonably included among the list of fortified sites overlooking the "House of Ammon".

\subsection{The enclosure}

The rectangular enclosure measured $41.56 \mathrm{~m}$ on the north-south axis and $37.8 \mathrm{~m}$ on the east-west, where almost half of the length was occupied by the square podium. By contrast, on the western side overlooking the road and the pass, the podium of the tower occupied only $1 / 3$ of the entire length of the fortress. The enclosure wall consisted of an exterior structure, around 1.45-1.55 m thick, and by a parallel thinner wall (0.8-1.0 m thick) inside, the two delimiting rectangular rooms all around the perimeter of the stronghold. The northwestern corner of the enclosure has been irremediably removed by the modern road cutting through the site, and also the northern side suffered major pillaging. Nonetheless, it seems clear that on this side the gate of the fort was located, with an outer passage $2.7 \mathrm{~m}$ wide and an inner one $2.1 \mathrm{~m}$ wide. The eastern side of the enclosure was the better preserved (fig. 6) and two soundings were excavated inside the casemates down to the earliest floor of the chamber which was upon bedrock (fig. 7).

Inside the entrance, about $10 \mathrm{~m}$ from it, there was the circular mouth of a cistern, carefully hewn into the bedrock. A drain possibly connected it to a drinking trough for caravans beverage. The eastern part of the entrance courtyard hosted, in the latest stratigraphic phase (Neo-Babylonian period), a stable. An inner courtyard flanked the tower and occupied the south-eastern quadrant of the fortress.

\subsection{The podium and the tower}

The podium occupied the south-western corner of the enclosure, overlooking the underlying pass and the track climbing it. It was preserved with 6 to 10 superimposed courses of stones, with some remains of the walls of the tower standing over it reaching an overall elevation of $4 \mathrm{~m}$ (fig. 8).The podium measured $14.42 \times 14.56 \mathrm{~m}$, with a basis slightly larger than the podium itself, so that a small step jutted off the face of the structure at its bottom. The monumental side-walls of the podium, 1.6-1.8 m thick, were made of large limestone blocks that had slightly battering faces (1/10), and reached the height of $3.12 \mathrm{~m}$ (6 cubits). The outer face of the podium was surprisingly well plastered with a thick layer of mortar and fine clayish light brown lime (fig. 9). Three very regular courses of blocks were standing on the crepidoma, roughly $0.46 \mathrm{~m}$ high, and followed by two other courses of roughly intermingled blocks and stones. This detail is possibly the spy of a reconstruction undergone by the building during its life. Big boulders reinforced its corners (fig. 10), and, on the eastern side, a ramp abutted on its corner to give access to the tower lying on top. The square basement was subdivided inside by three structures and the inner blind chambers were filled up with small stones.

Upon this raised podium, a square tower was erected, measuring $12.48 \times 12.48 \mathrm{~m}$ (24 cubits). The walls of the tower were made of blocks smaller in respect of those of the podium, laid on three rows, suggesting that this structure could reach a height at least of 9.4 
$\mathrm{m}$. The overall height of the building, podium plus tower, thus, was around $12.5 \mathrm{~m}$. The collapsed remains of the tower were quickly excavated, and the inner layout of this structure partly reconstructed. The entrance was from the eastern side, where a staircase and a ramp flanked the podium led to the tower upon it. The entrance was marked by the presence of door-socket of a distinguished Neo-Assyrian cylindrical elongated type (fig. 11); a second one, of the same shape and dimensions, was found by the door leading to the staircase made of wood. This allowed to reach the upper floor and the roof from the room in the south-western corner of the ground floor (fig. 12). The tower had in facts two storeys: the ground floor was possibly a vaulted hall, while the upper floor had flat ceiling as roof, which also served to watch all around.

\section{POTTERY AND OTHER FINDS}

A selection of pottery and finds is illustrated here, in the meanwhile that all pottery and finds are processed and thoroughly studied. The selection focused on destruction layers inside the tower, where pottery and finds were collected in its latest layers of use.

\subsection{Pottery shapes}

Table Ware (fig. 13:1-3) includes mostly vessels coated with a dark brownish Red Slip, sometimes roughly burnished with a wooden tool. A plate (saucer) of coastal tradition was found, ${ }^{37}$ coated with a highly burnished Red Slip, as like as some carinated bowls with emboldened or expanded rim. These are among the most common open shapes in late Iron IIC (c. 680-580 BC) Ammonite contexts. ${ }^{38}$ Dipper jugs and juglets are also coated with a thick brownish slip (fig. 13:4-5). ${ }^{39}$ Cooking jugs (fig. 14:1), pots (fig. 14:2-3), ${ }^{40}$ craters (fig. 14:4-5), ${ }^{41}$ storage jars and pithoi (fig. 14:6-7) fit well in the late Iron IIC ceramic horizon of Ammon, and may reflect some Neo-Assyrian influx depending on the style of so-called Palace Ware. ${ }^{42}$

\subsection{Finds: stone tools and duck-weight}

A distinguished set of stone tools was collected on the floor of the south-eastern room of the Tower (locus L.27): two round pierced counter weights (fig. 15); a mortar bowl with a cylindrical basalt stone pestle (fig. 16); a balance weight made of red quartzite, in the shape of a duck, unfortunately with eroded head (fig. 17). The latter weights $345 \mathrm{~g}$, and, with the integrated missing part, it should correspond to 1 light mina (MA.NA) of the NeoAssyrian weighing system. Duck-weights are common in Neo-Assyrian and NeoBabylonian contexts, especially palaces, residencies and administrative buildings, with the size of light mina (about $480 \mathrm{~g}$ ) or heavy or double mina (about $1 \mathrm{Kg}$ ), ${ }^{43}$ while they are

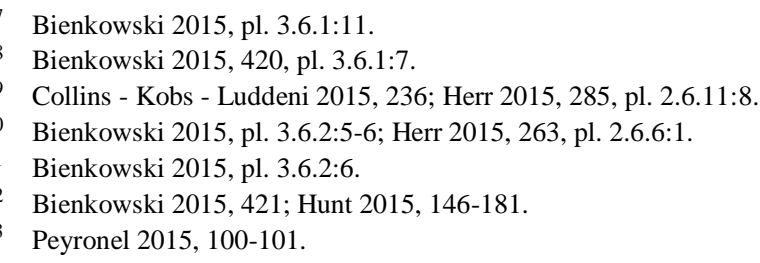


usually of reduced size in tombs, transformed into beads. This noteworthy find may support the interpretation of the stronghold being devoted not only to territorial control and defensive purposes, but also to administrative functions.

\subsection{The head of a male statue}

An almost unique find from the fortress of Jamaan, retrieved in the destruction layer of the tower, near the approaching ramp, is the head of a fine limestone statuette portraying a male personage (fig. 18). The sculpture is roughly carved (partially incised) and its surface also shows some graffiti. The statue is $13 \mathrm{~cm}$ high, and, thus, is of quite reduced size also in respect of already known Ammonite sculptures, found in 'Amman or in its surroundings. ${ }^{44}$ Also its stylistic quality is lower in respect of those found in the capital of the kingdom. The male head is without beard, conversely in respect of the other known contemporary male statues, and exhibits a distinguished hairstyle (fig. 19), that is a neat separation of radial 'rasta-like' dreadlocks. Eyes and ears are very schematically carved, and eyebrows are disharmonically unified. The iconography of the personage is that of a high official or a military chief, but can hardly be associated with royal statuary or cult statues as the other known examples from the Kingdom of Ammon. ${ }^{45}$ It may recall some Arab of Madianite hairstyle, as it is suggested by the comparisons with Arabs riding camels visible on Ashurbanipal's reliefs from Room L in his North Palace in Niniveh, where his war against the Arab Queen Adiâ is carved. ${ }^{46}$

\section{DATING AND INTERPRETATION}

No samples were available (due to the long exposure of the latest strata excavated so far during the two rescue seasons at Jamaan) to undergo radiocarbon analyses, so that the only possible dating, beyond the exam of architectural features (§ 4.), is that suggested by finds and, notably, pottery. The majority of collected ceramic fragments are from the uppermost layers of the Tower and from soundings inside some casemates of the enclosure. This pottery belongs to a typical so-called 'Ammonite' Late Iron IIC horizon, where NeoAssyrian, and also Neo-Babylonian influxes are noticeable, both in shapes and in the dark red-brownish burnished surface treatment of vessels. ${ }^{47} \mathrm{~A}$ reasonable date is between the end of the $7^{\text {th }}$ and the beginning of the $6^{\text {th }}$ century BC. Earlier ceramic fragments, going back to one century or more before in Iron IIB, were also found. This ceramic evidence fits well with the historical interpretation of the building as a stronghold erected in the $9^{\text {th }}$

44 Abou Assaf 1980; Ornan 1986, 36-39; 'Amr 1990; Burnett 2016a; 2016c. Monumental stone statues representing gods and human kings are also known in northern Syria and Assyria (Strommenger 1970, 10-28; Orthmann 1971, 476, 522545).

45 In Ammonite statuary, the element characterizing the gods is the atef crown (Mallowan - Herrmann 1974, 106; Negbi 1976, 31; Abou Assaf 1980, 78; Daviau - Dion 1994; Burnett 2009; 2016a, 58-65; 2016c, 30-31), as for the Egyptian god Osiris (Griffiths 2001) and the Egyptian kings in a long lasting Levantine tradition (Scandone Matthiae 1990, 147, 149). Conversely, Ammonite kings' statues are characterized by the presence of a hadband or diadem, as shown by the statue of Yerah-azar (Abou Assaf 1980, pl. VI; Burnett 2016c, 6465).

46 Dolce 1995, 36-37, fig. 6; Nigro 1995, fig. 126; Matthiae 1996, 186, fig. 9.6.

47 Gilboa - Sharon 2016, fig. 4:2. 
century BC to protect the northern border of Ammon. The fortress included a watching tower and an enclosure, perhaps used also for administrative purposes connected to caravan trade, and for the pass control. The stronghold material culture shares many aspects of socalled 'Ammonite' horizon - known from excavations in Jebel 'Amman, and in other kindred sites. ${ }^{48}$ The retrieval of the broken head of a small statue (figs. 18-19) is coherent with this picture, as the Kingdom of Ammon is characterized in its main centres by the presence of such pieces of statuary. Nonetheless, its style may indicate a late Neo-Assyrian influx, as it reminds some Arab personages in Ashurbanipal's reliefs of the North Palace in Niniveh. Moreover, the finding of a duck-weight also points to this direction. All these elements testify to the nowadays unfortunately disappeared fortress being part of the defensive and administrative system of the Kingdom of Ammon also during the NeoAssyrian and Neo-Babylonian domination.

\section{REFERENCES}

Abou Assaf, A.

1980 Untersuchungen zur ammonitischen Rundbildkunst: Ugarit-Forschungen 12 (1980), pp. 7-102.

ALBRIGHT, W.F.

1970 Some Comments on the 'Ammân Citadel Inscription: Bulletin of the American Schools of Oriental Research 198 (1970), pp. 38-40.

'AMR, A.-J.

1990 Four Ammonite Sculptures from Jordan: Zeitschrift des Deutschen Palästina-Vereins 106 AUFRECHT, W.E. (1990), pp. 114-118.

1989 A Corpus of Ammonite Inscriptions, New York 1989.

BARTLETT, J.R.

1970 Sihon and Og, Kings of the Amorites: Vetus Testamentum 20/3 (1970), pp. 257-277. BIENKOWSKI, P.

1991 The Art of Jordan. Treasures from an Ancient Land, Phoenix 1991.

2015 Iron Age IIC Transjordan: S. GiTin (ed.), The Ancient Pottery of Israel and its Neighbors. From the Iron Age through the Hellenistic Period (Israel Exploration Society), Jerusalem 2015, pp. 419-434.

BONFIL, R. - ZARZECKI-PELEG, A

2007 The Palace in the Upper City of Hazor as an Expression of a Syrian Architectural BURNETT, J.S. Paradigm: Bulletin of the American Schools of Oriental Research 348 (2007), pp. 25-47.

2009 Iron Age Deities in Word, Image, and Name: Correlating Epigraphic, Iconographic, and Onomastic Evidence for the Ammonite God: Studies in the History and Archaeology of Jordan 10 (2009), pp. 153-164.

2016a Egyptianizing Elements in Ammonite Stone Statuary: The Atef Crown and Lotus: R.A. STUCKY - O. KAELIN - H.-P. MATHYs (eds.), Proceedings of the $9^{\text {th }}$ International Congress

48 Burnett 2016c. 
on the Archaeology of the Ancient Near East, Volume 1 (9-13 June 2014, Basel), Wiesbaden 2016, pp. 57-69.

2016b Transjordan: The Ammonites, Moabites, and Edomites: B.T. ARNOLD - B.A. STRAwn (eds.), The World around the Old Testament: The Peoples and Places of the Ancient Near East, Grand Rapids 2016, pp. 309-352.

2016c Ammon, Moab and Edom. Gods \& Kingdoms East of the Jordan: Biblical Archaeology Review (November/December 2016), pp. 26-67.

CLARK, V.A.

1983 The Iron IIC/Persian Pottery from Rujm al.Henu: Annual of the Department of Antiquities of Jordan 27 (1983), pp. 143-163.

Collins, S. - KoBs, C.M. - LudDENI, M. C.

2015 The Tall al-Hammam Excavations. Volume 1. An Introduction to Tall al-Hammam with Seven Seasons (2005-2011) of Ceramics and Eight Seasons (2005-2012) of Artifacts, Winona Lake 2015.

DAVIAU, P.M.M. - DiON, P.E.

1994 El, the God of the Ammonites? The Atef-Crowned Head from Tell Jawa, Jordan: Zeitschrift des DeutschenPalästina-Vereins 110 (1994), 158-167.

DOLCE, R.

1995 Concezioni e rappresentazioni del potere: la Maestà, il Dominio, il Prestigio: R. DoLCE M. Nota Santi (edd.), Dai Palazzi Assiri: Immagini di Potere da Assurnasirpal II ad Assurbanipal (IX-VII sec. a.C.) (Studia Archaeologica 76), Roma 1995, pp. 25-43.

FOHRER, G.

1961 Eisenzeitliehe Anlagen im Raume sudlieh von Naur und die sudwestgrezen von Ammon: Zeitscrift des Deutschen Palästina-Vereins 77 (1961), pp. 56-71.

GESE, $H$.

1958 Ammonitische Grenzfestungen zwischen wadi es-Sir und Naur: Zeitscrift des Deutschen Palästina-Vereins 74 (1958), pp. 55-64.

GiLBOA, A. - SHARON, I.

2016 The Assyrian kāru at Dor (ancient Du'ru): J. MACGinnis - D. WiCKE - T. GREenfFIELD (eds.), The provincial archaeology of the Assyrian Empire, Cambridge 2016, pp. 241-252

GLUECK, N.

1939 Explorations in Eastern Palestine, III (1937-1939) (The Annual of the American Schools of Oriental Research 18-19), New Haven 1939.

GORDON, R.L. - KNAUF, E.A.

1987 Er-Rumman Survey 1985: Annual of the Department of Antiquities of Jordan 31 (1987), pp. 289-298.

GRAF-REVCMLOW, $\mathrm{H}$.

1963 Grenzbesfestigungskette: Zeitschrift des Deutschen Palästina-Vereins 79 (1963), pp. $127-$ 137.

GRIFFITHS, J.G.

2001 Osiris: D.B. REDFord (ed.), The Oxford Encyclopaedia of Ancient Egypt, New York 2001, pp. 615-619.

HENTSCHKE, R.

1960 Ammonitische Grenz festungen sudwestlich von Amman: Zeitschrift des Deutschen HERR, L.G. Palästina-Vereins 76 (1960), pp. 103-123.

2015 Iron Age IIA-B: Transjordan: S. Gitin (ed.), The Ancient Pottery of Israel and its Neighbors. From the Iron Age through the Hellenistic Period (Israel Exploration Society), Jerusalem 2015, pp. 281-299. 
HORN, S.H.

1969 The Ammān Citadel Inscription: Bulletin of the American Schools of Oriental Research HÜBNER, U. 193 (1969), pp. 2-13.

1992 Die Ammoniter: Untersuchungen zur Geschichte, Kultur umd Religion eines Transjordanischen Volkes im I. Fahrtausend V. Ch. (Abhandlungen des Deutschen Palästina Vereins Band 16), Wiesbaden 1992.

HunT, A.M.W.

2015 Palace Ware Across the Neo-Assyrian Imperial Landscape. Social Value and Semiotic JOFFE, A.H. Meaning (Culture and History of the Ancient Near East 78), Leiden - Boston 2015.

2002 The Rise of Secondary States in the Iron Age Levant: N. YofFEE (ed.), Excavating the Relations between Archaeology and History in the Study of Pre-Modern Asia [Part 1] (Journal of the Economic and Social History of the Orient 45/4), Leiden 2002, pp. 425467.

KLETTER, R.

1991 The Rujm El-Malfuf Buildings and the Assyrian Vassal State of Ammon: Bulletin of the LANDES, G.M. American Schools of Oriental Research 284 (1991), pp. 33-50.

1961 The Material Civilization of the Ammonites: Biblical Archaeologist 24 (1961), pp. 66-86. LAWSON YOUNGER JR., K.

2003 Kurkh Monolith: W.W. Hallo - K. LAWson Younger JR. (eds.), The Context of Scripture: Monumental Inscriptions from the biblical world, Volume 2, Leiden 2003, pp. 261-264.

LeHMANN, G. - KiLLEBREW, A.E.

2010 Palace 6000 at Megiddo in Context: Iron Age Central Hall Tetra-Partite Residencies and the Bìt-Hilāni Building Tradition in the Levant: Bulletin of the American Schools of Oriental Research 359 (2010), pp. 13-33.

LENZEN, C.J. - MCQUITTY, A.M.

1987 The Site of Khirbet Salameh: Annual of the Department of Antiquities of Jordan 33 (1987), pp. 201-204.

1989 Salameh (Khirbet): D. HomÈs-FrEDERICQ - J.B. HENNESSY (eds.), Archaeology of Jordan, Vol. II-2: Field Reports: Sites L-Z (Akkadica Supplementum 8), Leuven 1989, pp. 543546.

LIPSCHITS, O.

2004 Ammon in Transition from Vassal Kingdom to Babylonian Province: Bulletin of the American Schools of Oriental Research 335 (2004), pp. 37-52.

LUCKENBILL, D.D.

1927 Ancient Records of Assyria and Babylonia, II: Historical Records of Assyria from Sargon MACDONALD, B. to the End, Chicago 1927.

1999 Ammonite territory and sites: B. MacDonALD - R.W. Younker (eds.), Ancient Ammon (Studies in the History and Archaeology of the Ancient Near East 17), Leiden 1999, pp. 30-56.

Mallowan, M. - HeRrmanN, G.

1974 Furniture from SW.7 Fort Shalmaneser. Ivories from Nimrud (1949-1963), Fascicle III, London 1974. 
MANSOUR, S.

2002 Preliminary Report of the Excavations at Jebel al-Qal`a (Lower Terrace): The Iron Age MatThiae, P.

Walls: Annual of the Department of Antiquities of Jordan 46 (2002), pp. 141-150.

$1996 \quad$ L'arte degli Assiri. Roma - Bari 1996.

MCGOVERN, P.E.

1983 Test Soundings of Archaeological and Resistivity Surveys Results at Rujm Al-Henu: Annual of the Department of Antiquities of Jordan 27 (1983), pp. 105-141.

1986 The Late Bronze Age and Early Iron Ages of Central Transjordan: the Baq'ah Valley Project, 1977-1981, Philadelphia 1986.

1989 Baq'ah Valley Project - Survey and Excavation: D. HoMÈs-FredERICQ - J.B. HeNNESSY (eds.), Archaeology of Jordan, Vol. II-1. Field Reports: Surveys and Sites A-K (Akkadica Supplementum 7), Leuven 1989, pp. 25-44.

MuHEISEN, M.

1976 Jbeyha church 1976[arabic]: Annual of the Department of Antiquities of Jordan 21 (1976), pp. 9-10.

NAJJAR, $M$.

1992 Rescue Excavations at Kilda/Amman: Annual of the Department of Antiquities of Jordan 36 (1992), pp. 12-20.

1999 “Ammonite” Monumental Architecture: B. MACDONALD - R.W. YounKeR (eds.), Ancient Ammon (Studies in the History and Archaeology of the Ancient Near East 17), Leiden 1999, pp. 103-112.

NEGBI, O.

1976 Canaanite Gods in Metal: An Archaeological Study of Ancient Syro-Palestinian Figurines (Publications of the Institute of Archaeology 5), Tel Aviv 1976.

NigRo, L.

1994 Ricerche sull'architettura palaziale della Palestina nelle età del Bronzo e del Ferro. Contesto archeologico e sviluppo storico (Contributi e Materiali di Archeologia Orientale V), Roma 1994.

1995 "Il Palazzo Nord di Assurbanipal a Ninive”: R. Dolce - M. Nota SANTi (edd.), Dai Palazzi Assiri: Immagini di Potere da Assurnasirpal II ad Assurbanipal (IX-VII sec. a.C.) (Studia Archaeologica 76), Roma 1995, pp. 264-271.

ORNAN, T.

1986 A Man and His Land: Highlights from the Moshe Dayan Collection, Jerusalem 1986.

ORTHMANN, W.

1971 Untersuchungen zur späthethitischen Kunst, Bonn 1971.

PEYRonel, L.

2015 The lion, the duck, and the scorpion. Royal Assyrian weights from the North-West Palace at Nimrud: Mesopotamia. Rivista di archeologia, epigrafia e storia orientale antica 50 (2015), pp. 93-112.

PRITCHARD, J.B. (ed.)

1969 Ancient Near Eastern Texts Relating to the Old Testament, Princeton 1969³.

PUECH, E.

1985 L'iscription de la statue d'Amman et la paléographie Ammonite: Revue Biblique 92 (1985), pp. 5-24.

RIPEPI, G.

2012 Gli edifici su podio in Palestina durante l’Età del Ferro II: Vicino Oriente XVI (2012), pp. 55-70. 
SALA, M.

2008 Along the river: 2007 survey of Upper and Middle Wadi az-Zarqa: L. NIGRO (ed.), Khirbet al-Batrawy II. The EB II city-gate, the EB II-III fortifications, the EB II-III temple. Preliminary report of the second (2006) and third (2007) seasons of excavations (Rome «La Sapienza» Studies on the Archaeology of Palestine \& Transjordan 6), Rome 2008, pp. 359-397.

SCANDONE MATthiAe, G.

1990 Egyptianizing Ivory Inlays from Palace P at Ebla: Annales archéologiques arabes syriennes 40 (1990), pp. 146-160.

STERN, E.

2001 Archaeology of the Land of the Bible, Volume II: The Assyrian, Babylonian and Persian Periods (732-332 B.C.E.), New York 2001.

STROMMENGER, E.

1970 Die neuassyrische Rundskulptur, Berlin 1970.

THOMPSON, H.O.

1972 The 1972 Excavations of Khirbet al-Hajjar: Annual of the Department of Antiquities of Jordan 17 (1972), pp. 47-72.

1973 Rujm Al-Malfuf South: Annual of the Department of Antiquities of Jordan 18 (1973), pp. 47-51.

1977 The Ammonite Remains at Khirbet al-Hajjar: Bulletin of the American Schools of Oriental Research 227 (1977), pp. 27-34.

1984 The Excavation of Rujm el-Mekheizin: Annual of the Department of Antiquities of Jordan 28 (1984), pp. 31-38.

THOMPSON, H.O. - ZAYADINE, F.

1974 The Works of Amminadab: The Biblical Archaeologist 37 (1974), pp. 13-19.

VAN DER VEEN, P.G.

2007 Gedaliah ben Ahiqam in the Light of Epigraphic Evidence (A Response to Bob Beeking): M. Lubetski (ed.), New Seals and Inscription, Hebrew, Idumean, and Cuneiform (Hebrew Bible Monograph 8), Sheffield 2007, pp. 55-70.

2012 'Milkom': J. EgGLER - C. UEHLINGER (eds.), Iconography of Deities and Demons in the YASSINE, K. Ancient Near East (http://www.religionswissenschaft.uzh.ch/idd/prepublication_4.php).

1988 Ammonite Fortresses, Date, and Function: K. YASSINE (ed.), Archaeology of Jordan: Essays and Reports, Amman 1988, pp. 11-31.

YOUNKER, R.W.

1999 Review of Archeological Research in Ammon: B. MacDonald - R.W. YounKer (eds.), Ancient Ammon (Studies in the History and Archaeology of the Ancient Near East 17), Leiden 1999, pp. 1-19.

ZAYADINE, F.

1991 Sculpture in Ancient Jordan: P. BIENKOwSKI (ed.), The Art of Jordan, Merseyside 1991, pp. 31-61.

ZAYADINE, F. - HuMBERT, J.B. - NAJJAR, M.

1989 The 1988 Excavations on the Citadel of Amman. Lower Terrace, Area A: Annual of the Department of Antiquities of Jordan 33 (1989), pp. 357-363. 


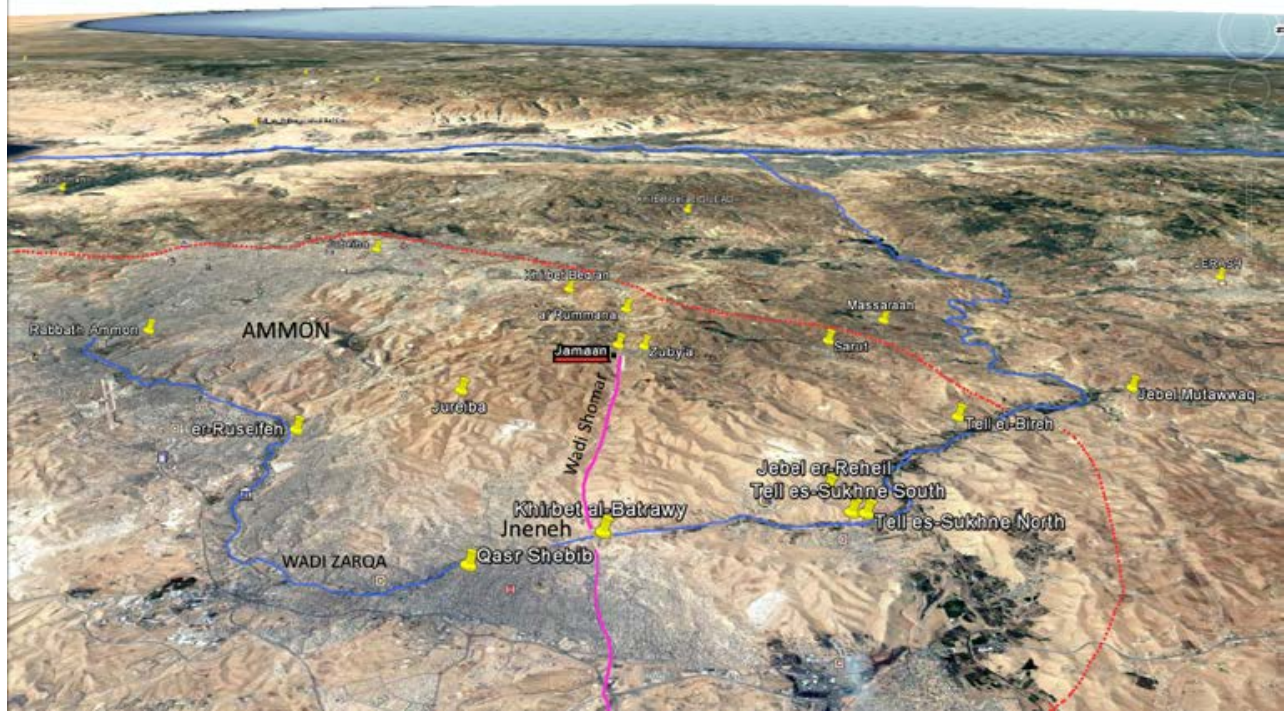

Fig. 1 - View of the territory of Kingdom of Ammon with the site of Jamaan looking west.

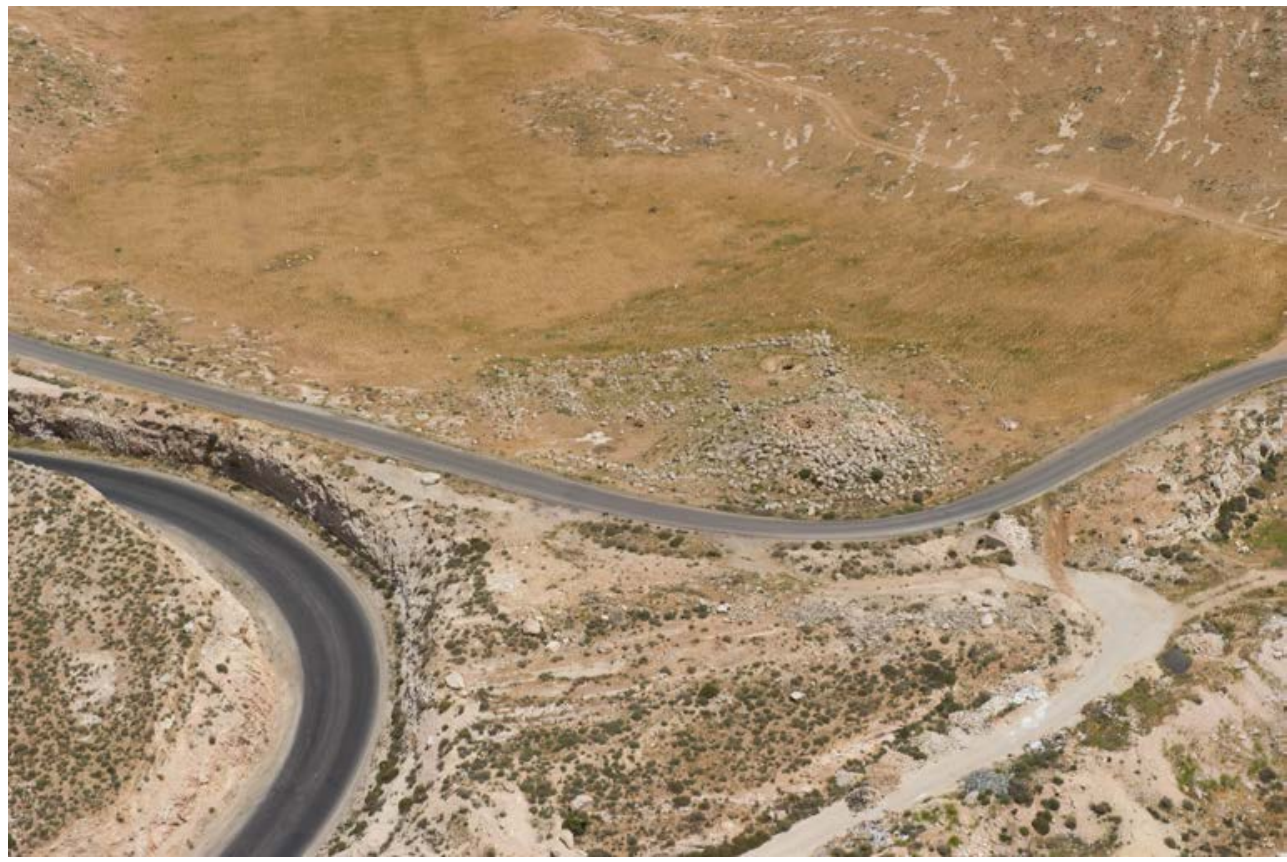

Fig. 2 - View of the site of Jamaan, cut through by the modern road, before rescue excavations (courtesy APAAME); in the foreground right the ancient road; from the northwest. 


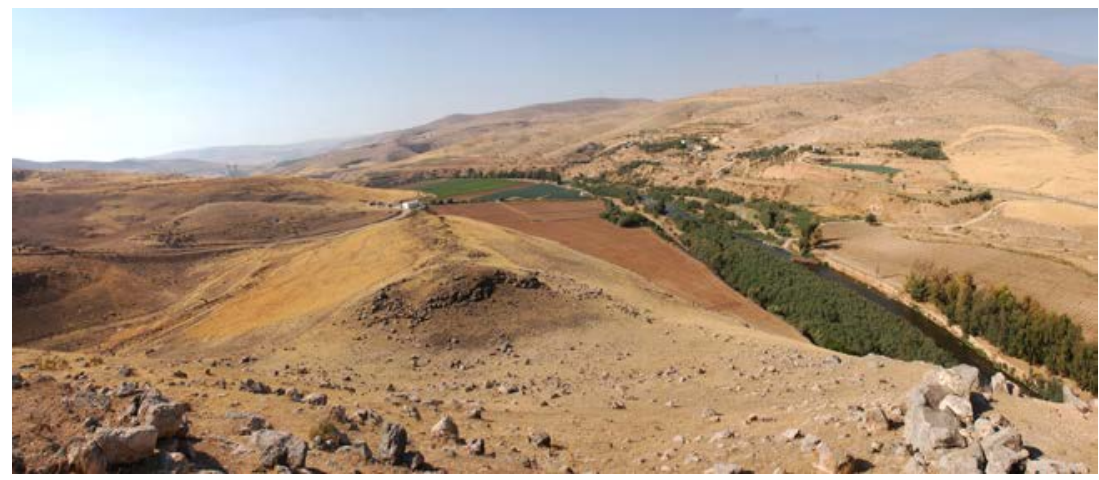

Fig. 3 - The site of Tell el-Bireh at the northern border of the Kingdom of Ammon.

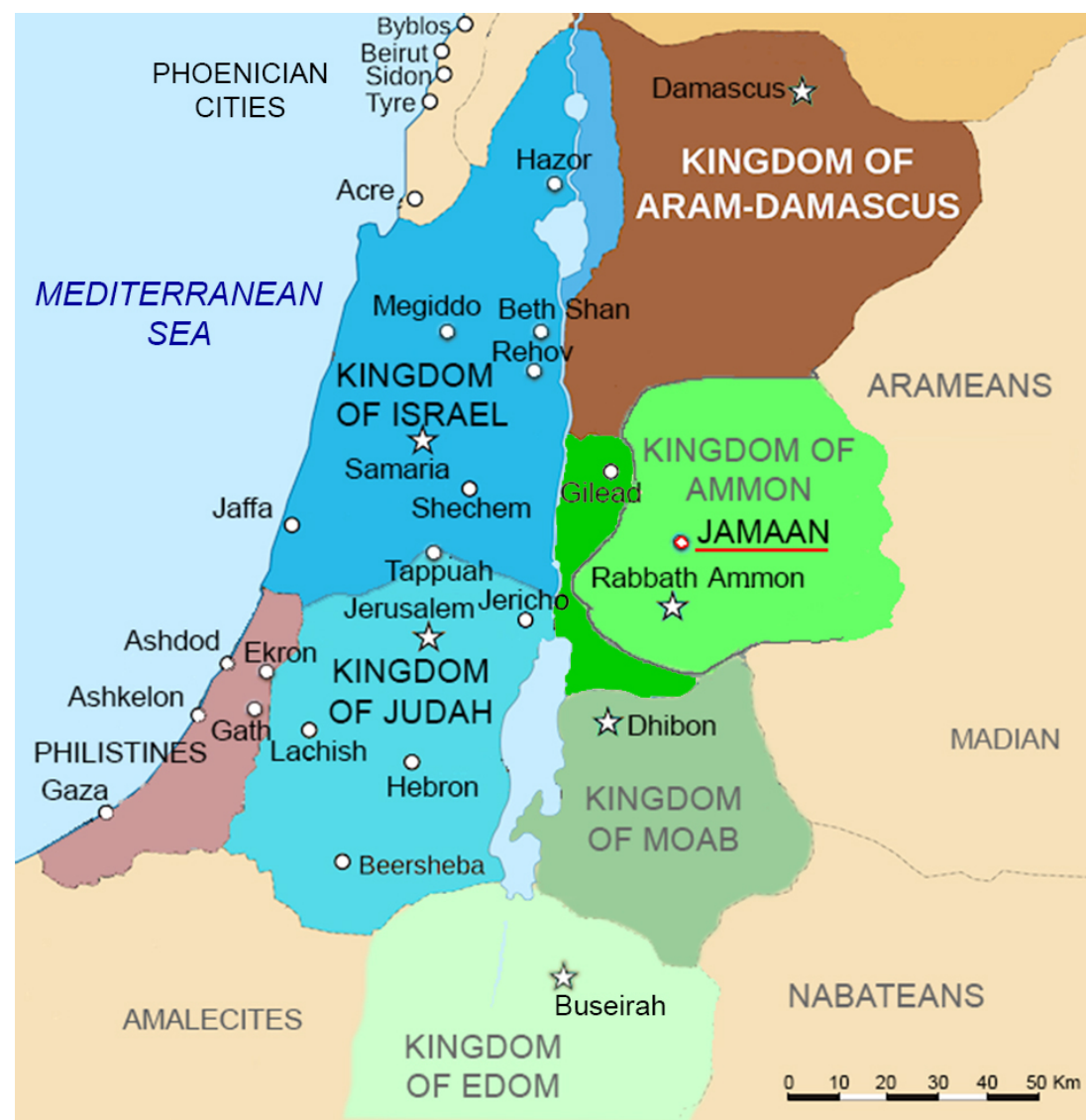

Fig. 4 - Map of Iron Age IIB-C Southern Levant with the location of Jamaan in the Kingdom of Ammon. 


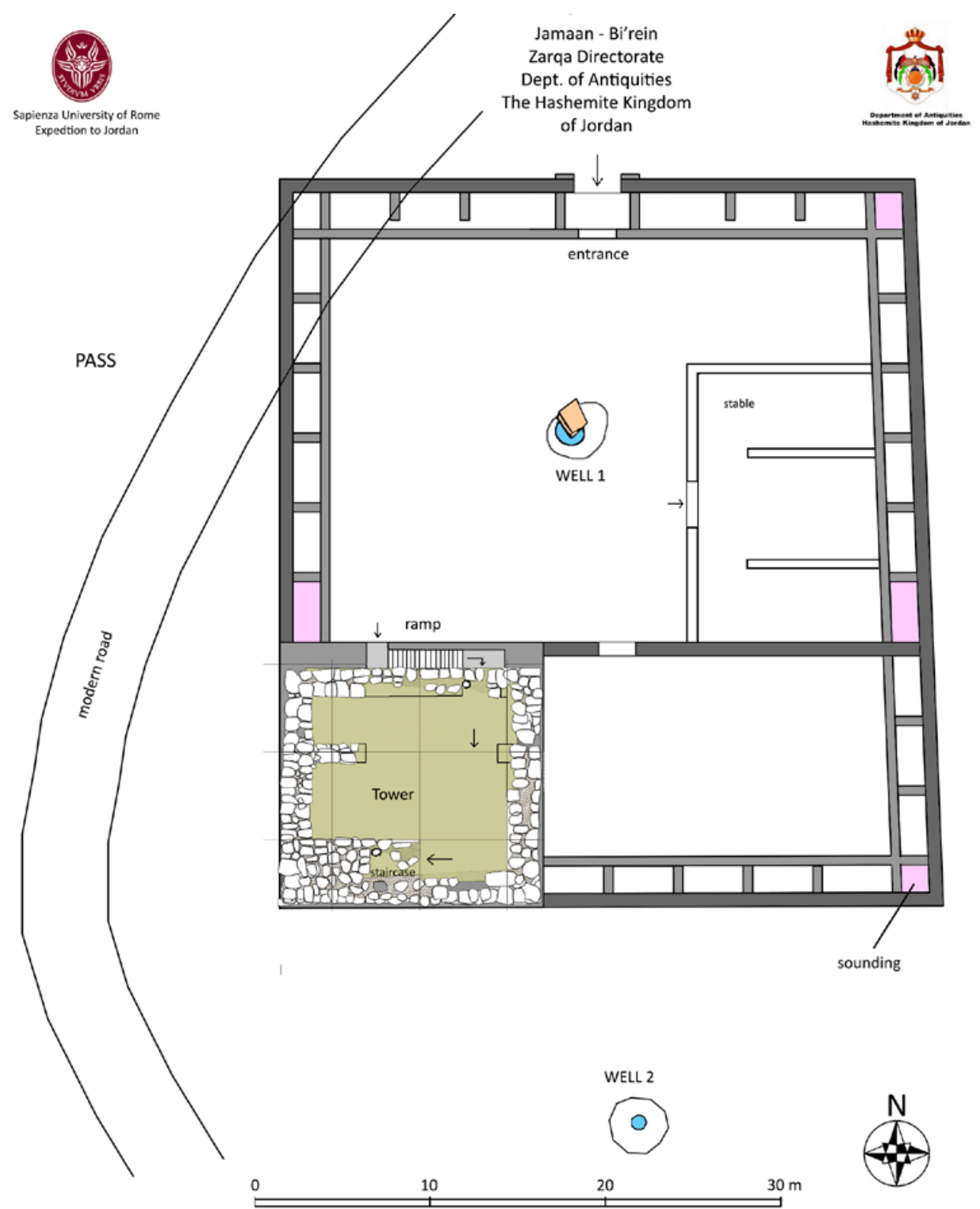

Fig. 5 - Reconstructive plan of the stronghold of Jamaan. 


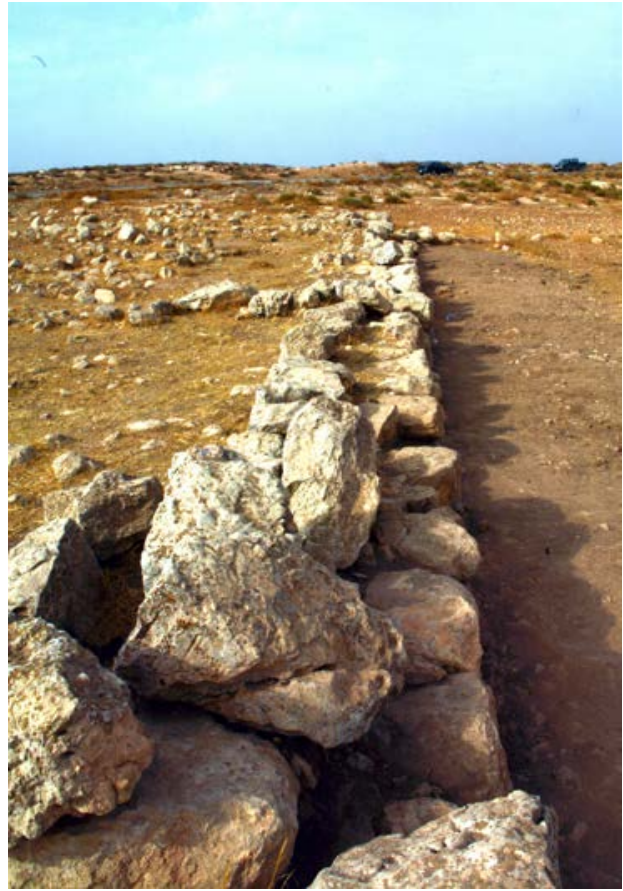

Fig. 6 - The eastern side of the enclosure; from the south.

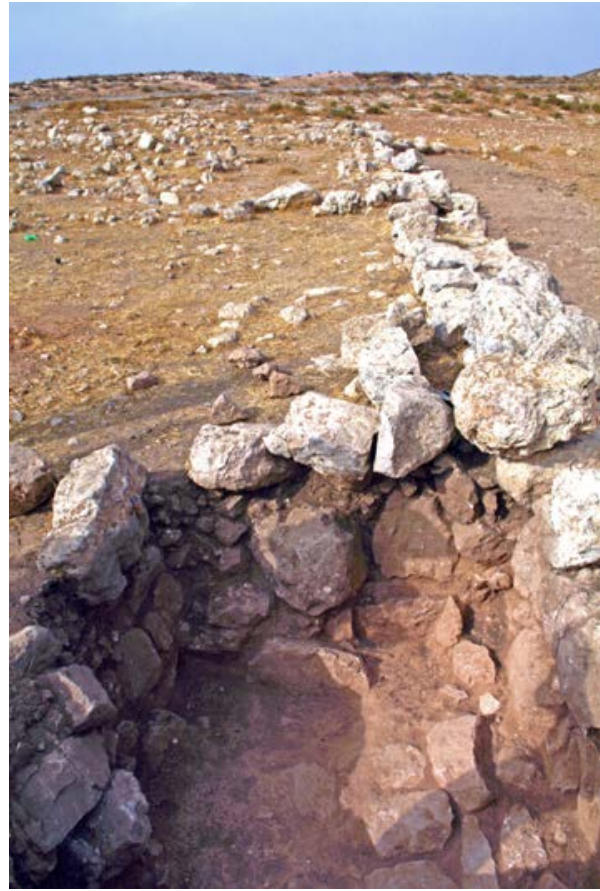

Fig. 7 - Sounding inside the casemate at the SE corner of the enclosure; from the south.



Fig. 8 - The SE corner of the podium; from the north-east. 


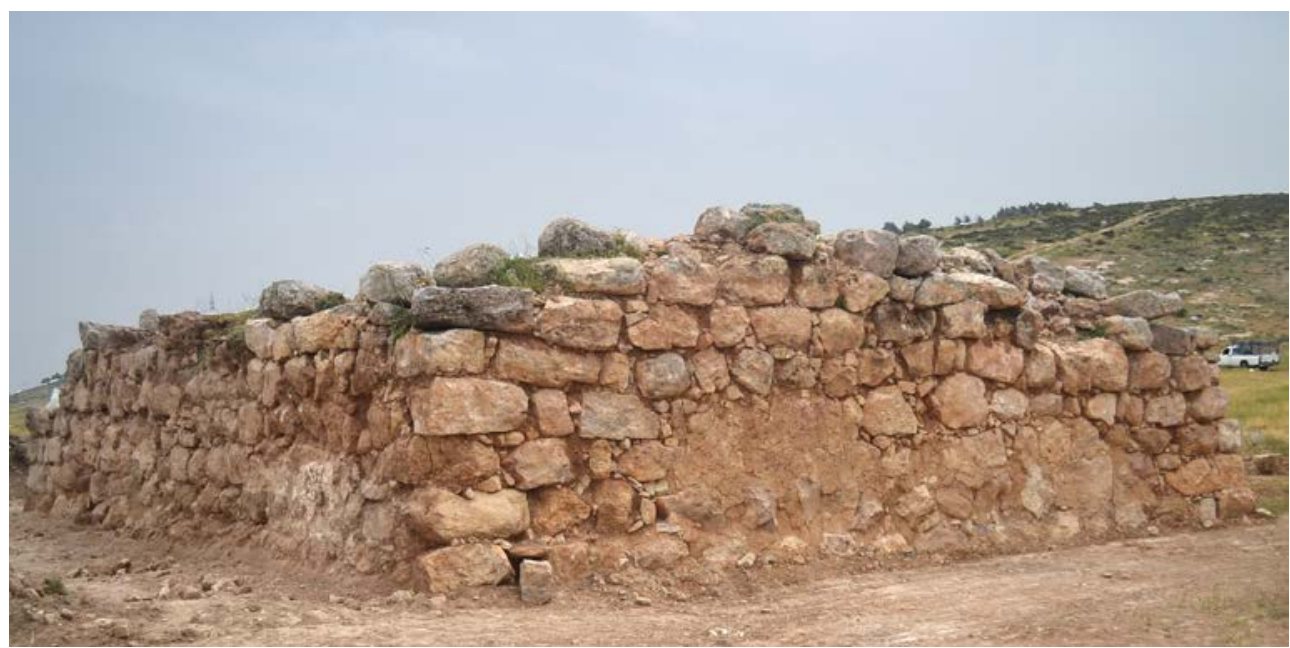

Fig. 9 - The NW corner of the podium with preserved original plaster; from the north-west.



Fig. 10 - The southern side of the podium; from the east. 

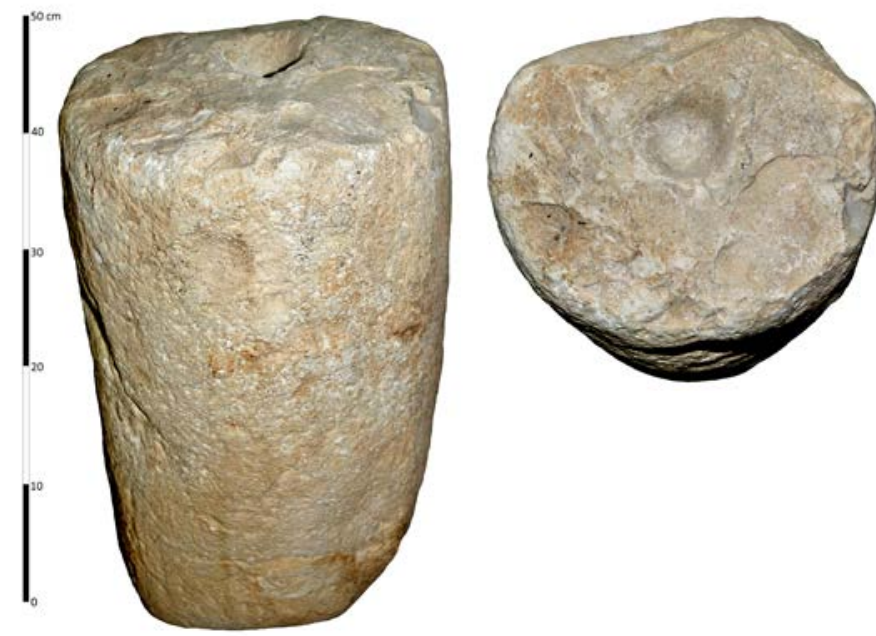

Fig. 11 - Stone doorsocket found at the entrance of the tower.



Fig. 12 - The SW room (L.27) of the ground floor of the tower. 


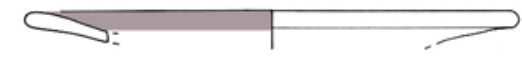

1. (JM.15.T27/12)

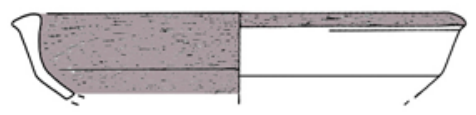

2. (JM.15.T27/1)

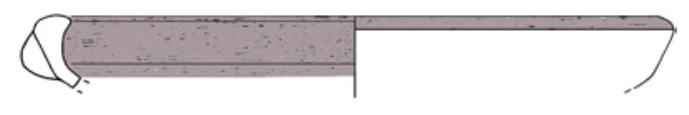

3. (JM.15.T27/2)
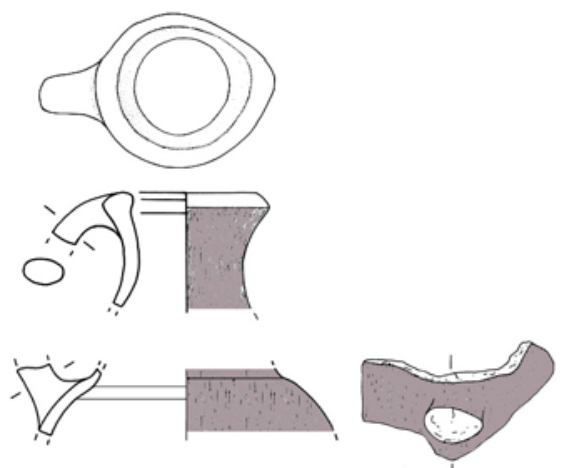

4. (JM.15.T27/4+7)
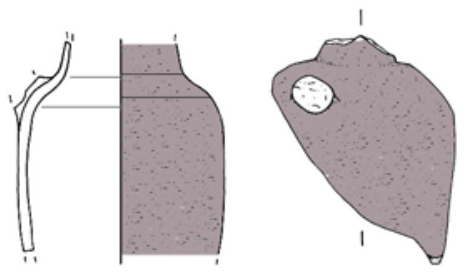

5. (JM.15.T27/5)

Fig. 13 - Iron Age IIB-C Table Ware from tower of Jamaan.

\begin{tabular}{|c|c|c|c|c|c|c|c|}
\hline \multirow{2}{*}{\begin{tabular}{l|}
$\mathbf{N}$. \\
1
\end{tabular}} & \multirow{2}{*}{$\begin{array}{l}\text { Type } \\
\text { Plate }\end{array}$} & \multirow{2}{*}{$\begin{array}{l}\text { Description } \\
\text { Shallow } \\
\text { plate/saucer }\end{array}$} & \multirow{2}{*}{$\begin{array}{l}\text { Fabric colour } \\
7.5 Y R 6 / 3 \\
\text { (light brown) }\end{array}$} & \multicolumn{2}{|c|}{ Surface treatment } & \multirow{2}{*}{$\begin{array}{l}\text { Dating } \\
\text { IA IIC }\end{array}$} & \multirow{2}{*}{$\begin{array}{l}\text { Comparisons } \\
\text { Bienkowski } \\
2015, \quad \text { pl. } \\
3.6 .1: 11\end{array}$} \\
\hline & & & & $\begin{array}{l}\text { Slip, burnish } \\
\text { (inner+outer) }\end{array}$ & $\begin{array}{l}2.5 Y R 5 / 4 \\
\text { (reddish } \\
\text { brown) }\end{array}$ & & \\
\hline 2 & Bowl & $\begin{array}{l}\text { Carinated bowl } \\
\text { with everted rim }\end{array}$ & $\begin{array}{l}\text { 5YR6/4 } \\
\text { (light reddish } \\
\text { brown) }\end{array}$ & $\begin{array}{l}\text { Slip, burnish } \\
\text { (inner+outer) }\end{array}$ & $\begin{array}{l}2.5 Y R 5 / 4 \\
\text { (reddish } \\
\text { brown) }\end{array}$ & IA IIC & $\begin{array}{l}\text { Bienkowski } \\
\text { 2015, 420, pl. } \\
\text { 3.6.1:7. }\end{array}$ \\
\hline 3 & Bowl & $\begin{array}{l}\text { Carinated bowl } \\
\text { with knob on the } \\
\text { rim }\end{array}$ & $\begin{array}{l}7.5 Y R 5 / 2 \\
\text { (brown) }\end{array}$ & $\begin{array}{l}\text { Slip, burnish } \\
\text { (inner+outer) }\end{array}$ & $\begin{array}{l}\text { 5YR5/2 } \\
\text { (reddish gray) }\end{array}$ & IA IIC & $\begin{array}{l}\text { Bienkowski } \\
\text { 2015, 420, pl. } \\
\text { 3.6.1:7. }\end{array}$ \\
\hline 4 & Juglet & $\begin{array}{l}\text { Dipper/juglet with } \\
\text { a slightly pinched } \\
\text { mouth }\end{array}$ & $\begin{array}{l}\text { 7.5YR7/2 } \\
\text { (pinkish gray) }\end{array}$ & $\begin{array}{l}\text { Slip, burnish } \\
\text { (outer } \\
\text { vertical) }\end{array}$ & $\begin{array}{l}7.5 Y R 4 / 2 \\
\text { (brown) }\end{array}$ & IA IIB-C & $\begin{array}{lr}\text { Herr } & 2015 \text {, } \\
285, & \text { pl. } \\
2.6 .11: 8 . & \end{array}$ \\
\hline 5 & Juglet & - & $\begin{array}{l}10 Y R 5 / 2 \\
\text { (grayish } \\
\text { brown) }\end{array}$ & $\begin{array}{l}\text { Slip, burnish } \\
\text { (outer) }\end{array}$ & $\begin{array}{l}7.5 Y R 4 / 2 \\
\text { (brown) }\end{array}$ & IA IIB-C & \\
\hline
\end{tabular}




\begin{tabular}{|c|c|c|c|c|c|c|c|}
\hline \multicolumn{8}{|c|}{ Figure 14 - Cooking Ware and Storage Ware from Locus 27 (Jamaan) } \\
\hline \multirow{2}{*}{\begin{tabular}{|l|}
$\mathbf{N}$. \\
1
\end{tabular}} & \multirow{2}{*}{\begin{tabular}{|l|} 
Type \\
Cooking \\
jug
\end{tabular}} & \multirow{2}{*}{\begin{tabular}{|l|} 
Description \\
$\begin{array}{l}\text { Cooking jug with } \\
\text { triangular rim }\end{array}$ \\
\end{tabular}} & \multirow{2}{*}{\begin{tabular}{|l|} 
Fabric colour \\
$7.5 Y R 5 / 3$ \\
(pink)
\end{tabular}} & \multicolumn{2}{|c|}{ Surface treatment } & \multirow{2}{*}{$\begin{array}{l}\text { Dating } \\
\text { IA IIC }\end{array}$} & \multirow{2}{*}{\begin{tabular}{|l|} 
Comparisons \\
Bienkowski \\
$2015, \quad$ pl \\
$3.6 .2: 6 \quad$ \\
\end{tabular}} \\
\hline & & & & - & - & & \\
\hline 2 & Pot & $\begin{array}{l}\text { Pot with vertical } \\
\text { neck and upright } \\
\text { rim }\end{array}$ & $\begin{array}{l}\text { 5YR6/6 } \\
\text { (reddish } \\
\text { yellow) }\end{array}$ & - & - & IA IIB-C & $\begin{array}{l}\text { Herr 2015, pl. } \\
\text { 2.6.6:1 }\end{array}$ \\
\hline 3 & Pot & $\begin{array}{l}\text { Cooking pot with } \\
\text { triangular rim and } \\
\text { handles extend } \\
\text { from the rim }\end{array}$ & \begin{tabular}{|l|} 
10YR4/4 \\
(dark yellowish \\
brown)
\end{tabular} & - & - & IA IIC & \begin{tabular}{|ll} 
Bienkowski \\
2015, & pl. \\
3.6.2:5-6 & \\
\end{tabular} \\
\hline 4 & Crater & $\begin{array}{l}\text { Globular crater } \\
\text { with inverted rim }\end{array}$ & $\begin{array}{l}7.5 Y R 7 / 4 \\
\text { (pink) }\end{array}$ & \begin{tabular}{|l|} 
Burnish \\
(outer on rim)
\end{tabular} & \begin{tabular}{|l|}
$7.5 Y R 7 / 4$ \\
(pink)
\end{tabular} & IA IIC & \begin{tabular}{|l} 
Bienkowski \\
2015, pl. \\
3.6.2:1
\end{tabular} \\
\hline 5 & Crater & $\begin{array}{l}\text { Globular crater } \\
\text { with inverted rim }\end{array}$ & \begin{tabular}{|l}
$\begin{array}{l}\text { 7.5YR7/4 } \\
\text { (pink) }\end{array}$ \\
\end{tabular} & - & - & IA IIC & \begin{tabular}{|l|} 
Bienkowski \\
2015, pl. \\
3.6.2:1
\end{tabular} \\
\hline 6 & Jar & $\begin{array}{l}\text { Hole-mouth jar } \\
\text { with simple rim }\end{array}$ & $\begin{array}{l}2.5 Y R 6 / 6 \\
\text { (light red) }\end{array}$ & - & - & IA IIC & $\begin{array}{l}\text { Bienkowski } \\
\text { 2015, 421, pl. } \\
\text { 3.6.3:1-2 }\end{array}$ \\
\hline 7 & Pithos & $\begin{array}{ll}\text { Pithos with } \\
\text { bulbous rim }\end{array}$ & $\begin{array}{l}\text { 10YR5/4 } \\
\text { (yellowish } \\
\text { brown) }\end{array}$ & - & - & IA IIC & \begin{tabular}{|l|} 
Bienkowski \\
2015, 421, pl. \\
3.6.3:1-2 \\
\end{tabular} \\
\hline
\end{tabular}




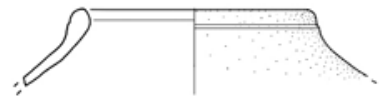

1. (JM.15.T27/3)

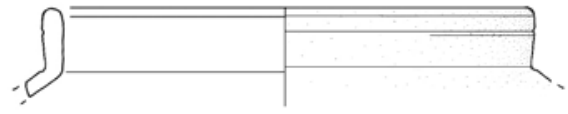

2. (JM.15.T27/11)

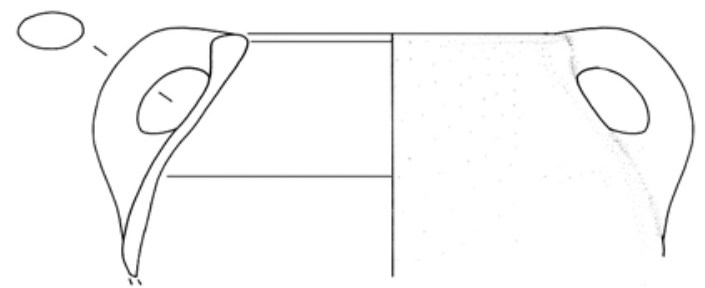

3. (JM.15.T27/9)

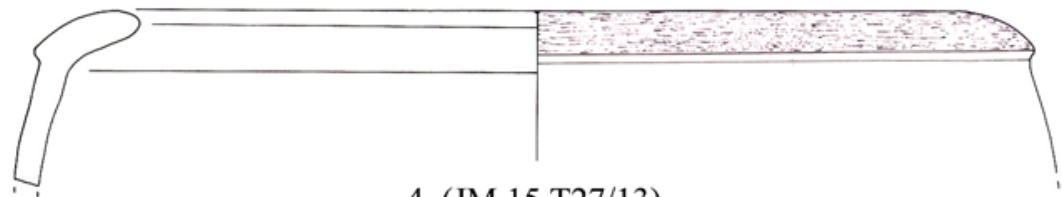

4. (JM.15.T27/13)

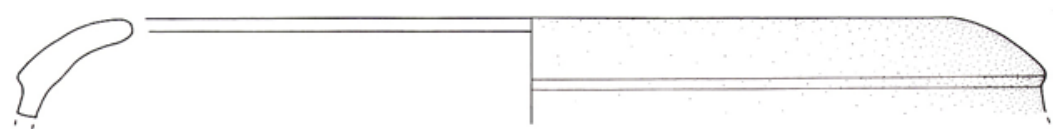

5. (JM.15.T27/14)

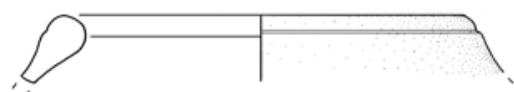

6. (JM.15.T27/8)

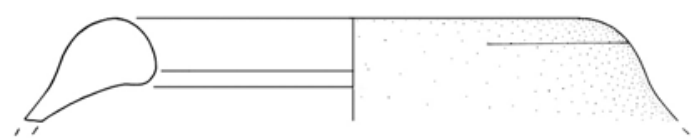

7. (JM.15.T27/10)

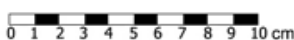

Fig. 14 - Iron Age IIB-C Cooking Ware and Storage Ware from tower of Jamaan. 


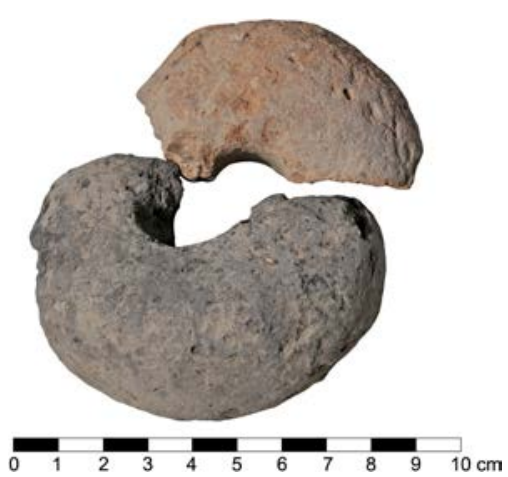

Fig. 15 - Two round pierced counter weights from the Jamaan tower.

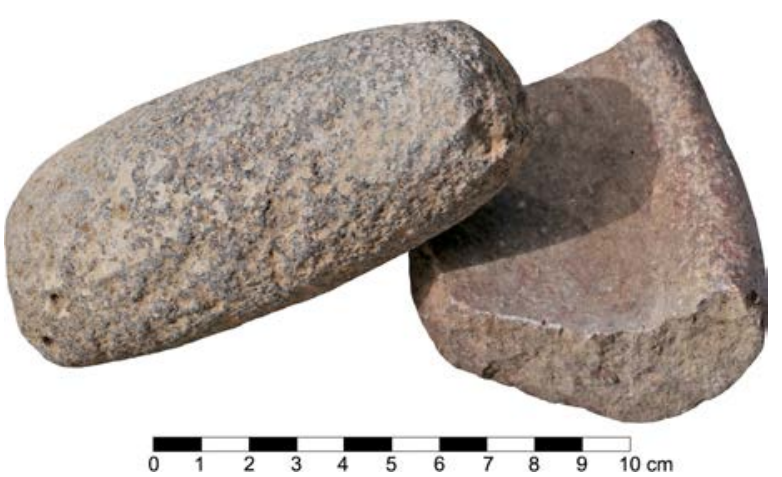

Fig. 16 - Mortar bowl and basalt cylindrical pestle found at Jamaan.
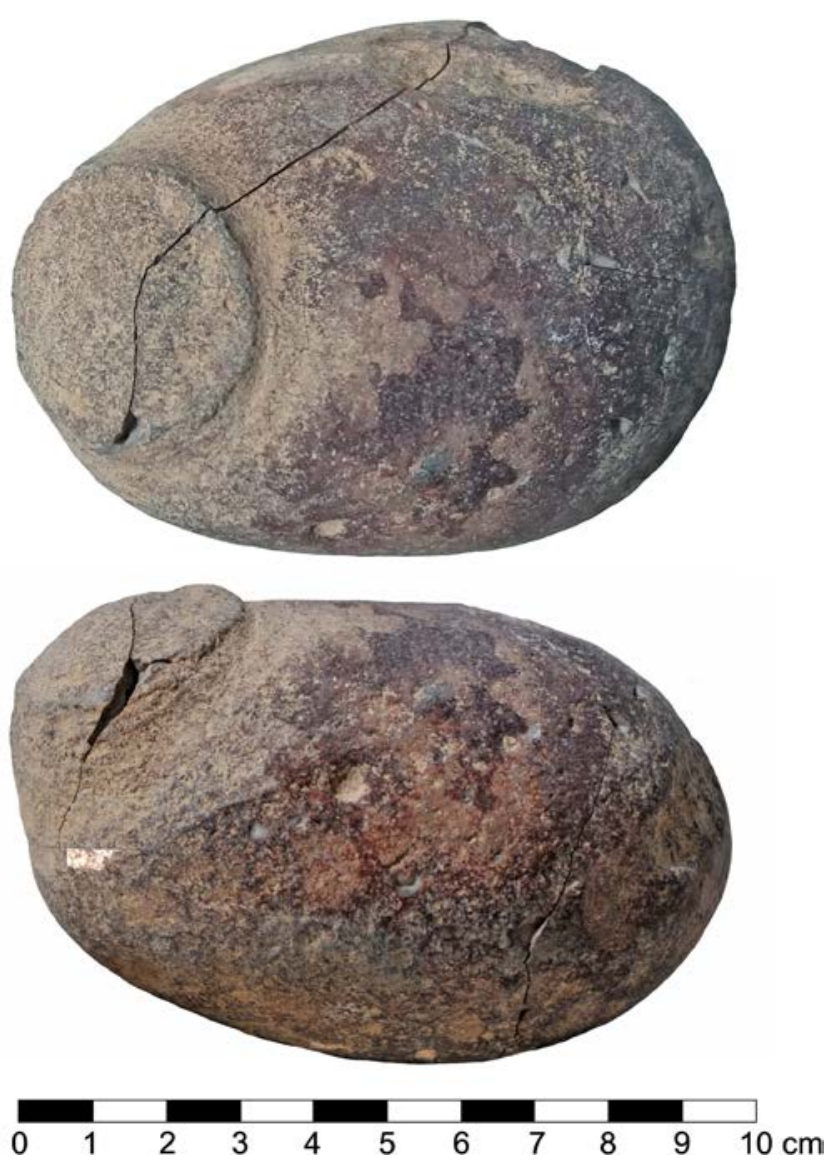

Fig. 17 - Duck-shaped red quartzite weight from Jamaan. 

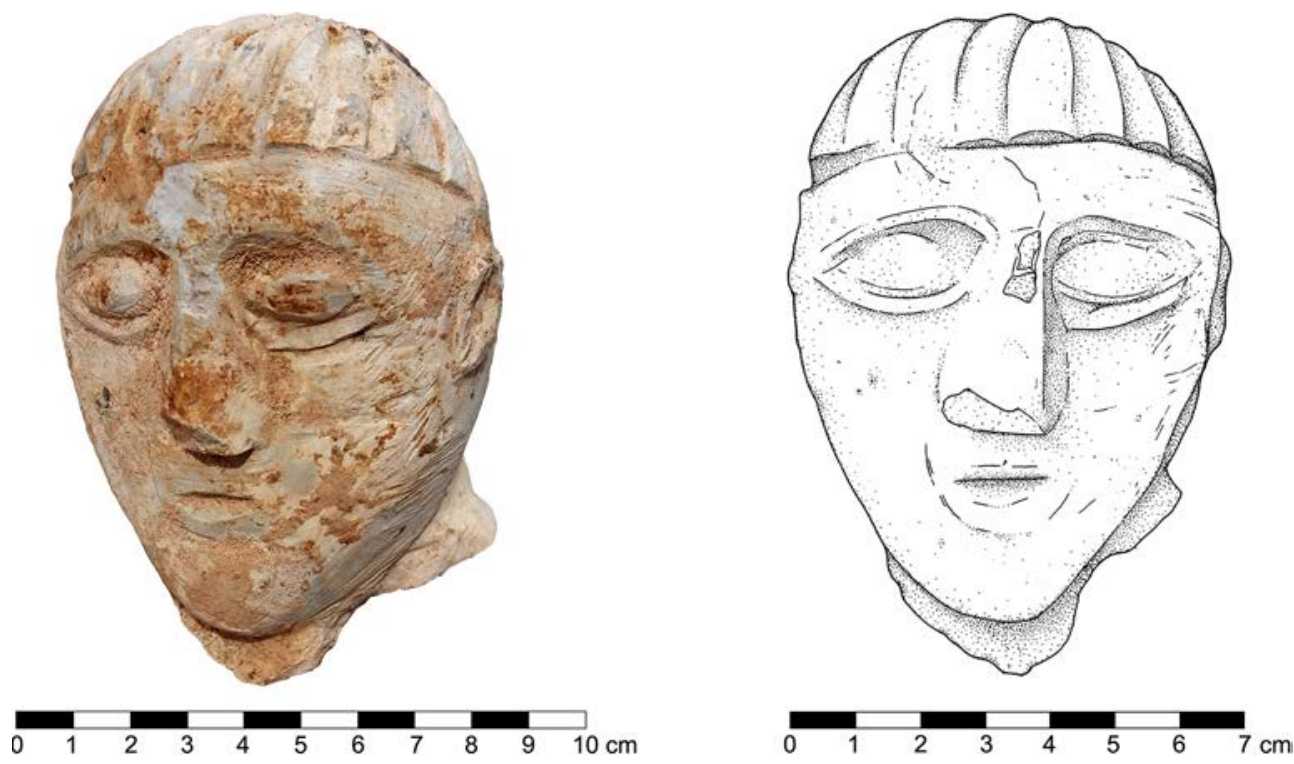

Fig. 18 - Head of the fine limestone statuette of a male personage, probably a high official or a ministry, found at Jamaan.
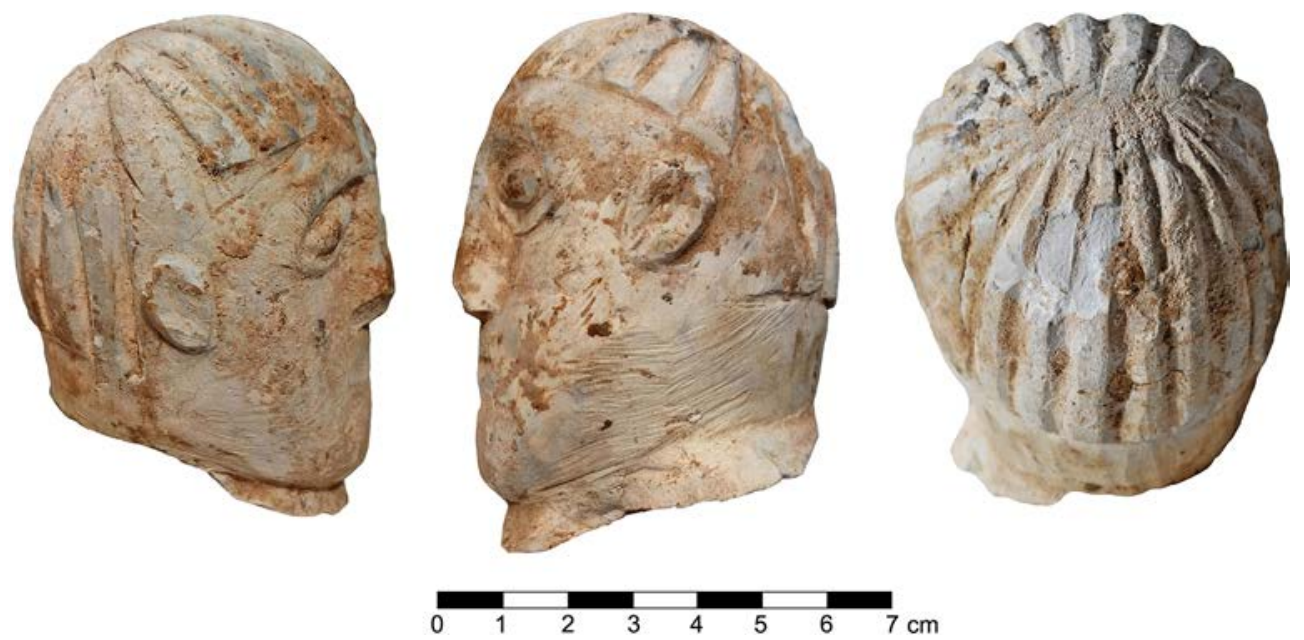

Fig. 19 - Lateral view of the limestone statuette found at Jamaan, with a detail of its hairstyle. 
ARABIC ABSTRACT

رجم جمعان ممر بيرين العصر الحديدي المبكر الثاني قبن الميلاد حصن العمونيون

وسط المملكة الأربنية الهاشمية الهبية

لوريثزو نيجرو- جامعة لاسبينزا في روما / رومل غريب ـمدير أثثار محافظة الزرقاء ـالاردن

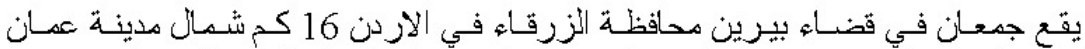

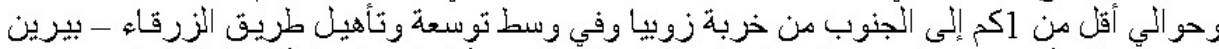



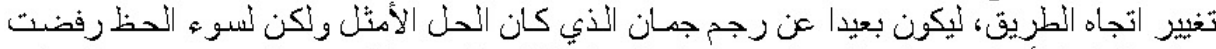

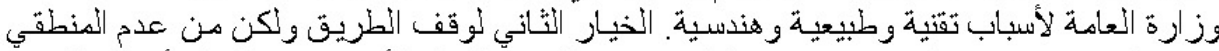

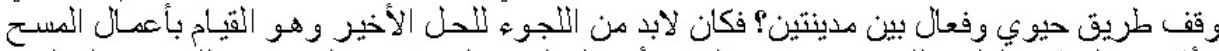

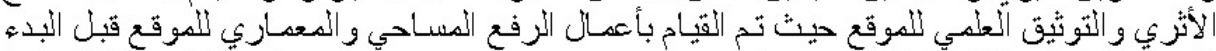

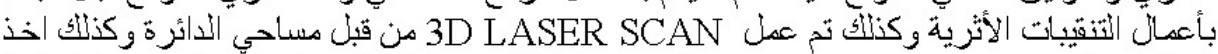

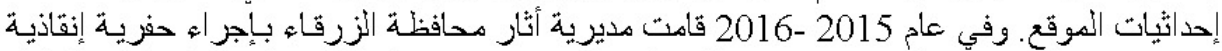

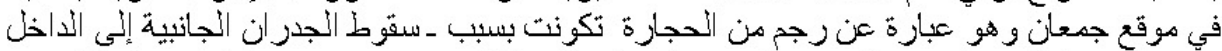

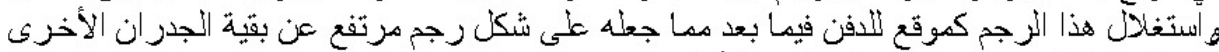

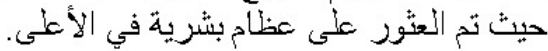

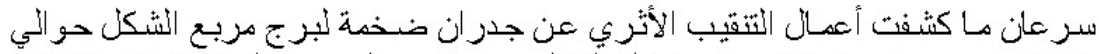

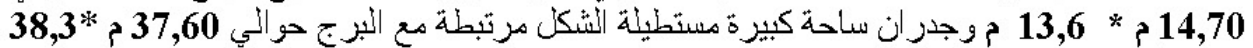



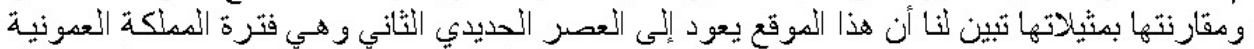

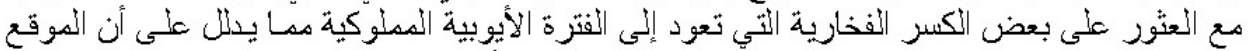

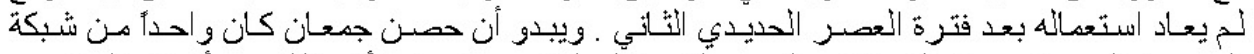

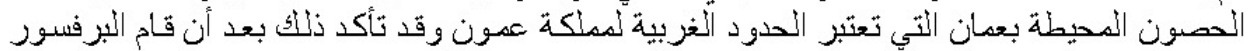

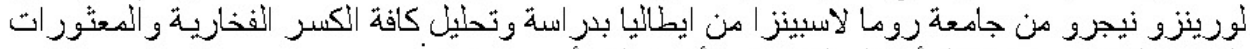



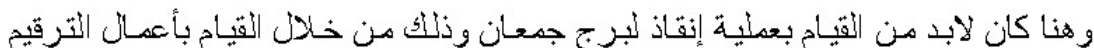

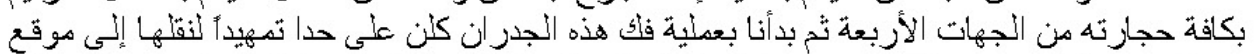



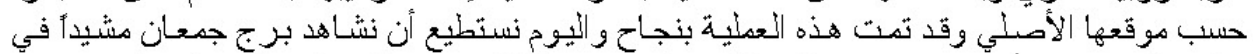

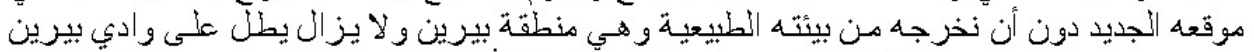

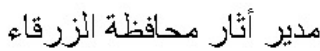

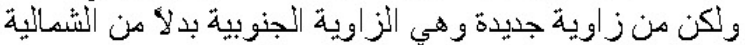

رومل غزيب 